\title{
Hemispheric Reconfigurations in Northern Amazonia: The 'Three Guianas' Amid Regional Change and Brazilian Hegemony
}

\begin{abstract}
Regional and hemispheric reconfigurations in Latin America and the Caribbean are increasingly mediated by Brazilian power, and the engagement of Guyana, Suriname and French Guiana with this emerging context is intriguing. They are tentatively moving away from a Caribbean region with which they are culturally contiguous, towards a South American continent in which they are geographically located. This is partly a reflection of the gradual opening up of the Northern Amazonian space that they share collectively, and with Venezuela and Brazil. These processes are occurring as cause and effect of Brazil's emergence as a regional - and even regionally hegemonic - power. With reference to wider debates on regionalism and hegemony, we analyse the uncertain consequences of these shifts.
\end{abstract}

On $29^{\text {th }}$ November 2010, Guyana, a small, English-speaking country on the north-eastern coast of South America, hosted the fourth summit of the new regional movement, the Union of South American Nations (UNASUR). This in itself was remarkable. Yet that day was significant in other respects, too. First, it witnessed the coming together of major Latin American Presidents - Luiz Inácio Lula da Silva of Brazil, Cristina Fernández de Kirchner of Argentina, Rafael Correa of Ecuador, Juan Manuel Santos of Colombia, and the late Hugo Chávez of Venezuela - many of them long-serving leaders with large personalities and deep reservoirs of influence. Second, the location of the meeting in Georgetown, and the fact that it was taken so seriously by the key players, suggested two things: that Guyana has now become more a South American country than a Caribbean one; and that UNASUR itself is emerging as the vehicle for a radically different kind of regionalism, something which has been reinforced by the group's increasing institutionalisation, along with the scope and ambition of its remit. ${ }^{1}$ Finally, the event encompassed two scenes reflecting the end of eras: the surprising, yet historic, embrace between Santos and Chávez, underlining, perhaps, a break in hostilities between their respective countries in a new context of Latin American unity; and one of Lula's final speeches as President before leaving office, in which he painted a vivid picture of his own country's dramatic growth and expansion over his two terms, along with the demonstrable increase in power Brazil now has to shape regional and international agendas. Indeed, what was particularly striking to anyone present was the size of the Brazilian delegation. In a room that held barely a couple of hundred people, Lula was flanked by dozens of technical and political personnel; the other leaders, by contrast, had small teams of just a handful each.

One of the most salient features of contemporary political change in Latin America and the Caribbean, then, is the emergence of Brazil as an increasingly influential power. At the same time, the significance of this process is generally poorly understood. This is particularly so given that the 'rise' of Brazil - along with its wider consequences for regional politics and diplomacy, new modes and models of development, or indeed, its place within the broader reordering of global North-South relations - is accompanied by a range of other concomitant shifts within the Western hemisphere. These include especially - but are not limited to - the creation of new mechanisms of regional co-operation, like UNASUR, that appear to be 
intensifying just as long-standing institutions of integrated governance seem to be undergoing a process of 'dis'-integration.

For Guyana and its two closest neighbours - Suriname and French Guiana - these changes pose fascinating challenges. This is because these 'Three Guianas' are simultaneously Caribbean and Latin American countries apart: they are socially, economically, culturally and politically contiguous with an island Caribbean region from which they are geographically isolated; yet they are physically tied to a continent from which they have long been culturally and linguistically alienated, in large measure because of the enormous barrier that the Amazon rainforest has historically represented. However, these boundaries are now beginning to break down, as a whole series of processes begin to make themselves felt, complicating the Guianas' relationship with each other, the wider Caribbean, and Latin America as a whole. ${ }^{2}$

As a consequence, not only do broader reconfigurations in what we might term 'Northern Amazonia' - that is, the enormous and often contested zone with fuzzy boundaries that is shared by the three territories, along with Brazil and Venezuela - carry interesting political implications for the Guianas themselves, but looking at these shifts through the prism of this unique space can also tell us more than a simple analysis of either regional change in general, or indeed the 'rise of Brazil' in particular, can alone. Such a discussion thus represents the core agenda of this article. We begin by engaging briefly with two distinct theoretical debates: questions of regionalism and regionalisation, and then issues of hegemony. By reflecting on and attempting to link these two disparate discussions - we shape the conceptual tools that underpin the subsequent substantive sections of the paper. The first of these discusses the structural dimensions of the problem. Specifically, it offers a historical and contextual account of regionalisation in the Caribbean and South America, and outlines how newly emergent patterns of hemispheric integration appear to be accompanied by simultaneous processes of dis-integration, each carrying a range of consequences for Guyana, Suriname, and French Guiana. The subsequent two sections deal with the agential side of the issue. They focus specifically on Brazil's emergence, the policy agendas driving its increasing influence in the wider region, and, in turn, the kinds of responses generated on the part of the Three Guianas, along with the consequences for them of the new regional environment. The conclusion ends by reflecting on the wider implications for how we should understand regionalism and hegemony, both practically and theoretically, in South America and the Caribbean and beyond.

\section{Regionalism and Hegemony}

At its most basic, the concept of regionalism refers to the conscious bringing together of different states and societies underpinned by a perceived need to pool resources and face external challenges collectively. As Payne and Gamble have suggested, 'regionalism is a stateled or states-led project designed to reorganize a particular regional space along defined economic and political lines'. ${ }^{3}$ Yet beyond this, there is much disagreement. Concepts like 'region, regional cooperation, regional integration, regionalism, regionalisation and regionbuilding' are, as Hettne notes, essentially 'moving targets'. ${ }^{4}$ This has led many to become 
disillusioned with definitional debates, but this, Hettne argues, is not a problem since a region is not something that occurs naturally; it is consciously constructed - both politically and ideationally - and therefore its definition is subject to political contestation. ${ }^{5}$

Debates pertaining to regionalism have developed significantly in recent years, partly as a reflection of the widespread proliferation of regional movements globally. However, as both the rationale for regionalism has changed over time, along with perceptions of it, the nature of both the phenomenon itself and the way it is understood have also evolved. Until the early 2000s, a distinction was generally drawn between the so-called 'Old' and 'New' regionalisms. The former is generally seen to be attendant with the study of integration in the European context, and focused primarily on inter-state bargains underpinned by the analytical categories prevalent in conventional International Relations (IR). In the context of the Cold War, this was an altogether more defensive, security-focused agenda. By contrast, after a lull in interest, the 1980 s and 1990s saw a resurgence in the study of regions, and this came in tandem with the apparent rise in integration movements which sought to develop external-facing structures while liberalising their markets internally. This was driven in large measure by the acceptance of neoliberal norms, and the belief that market integration on a regional scale would leave groups of countries better able to deal with the exigencies of globalisation. This was a surprising conversion on the part of often-marginalised countries and their elites that had traditionally been suspicious of global market integration and the promise of neoliberal reform. ${ }^{7}$ Moreover, not only was the New Regionalism fundamentally about managing globalisation, but its 'multidimensional, multi-actor, and multilevel character - or in short, complexity - was what distinguished it' $^{8}$.

This in turn has shifted debates about regionalism in four main ways that are of particular concern to us here. Ideologies of regionalism in the 1980s and 1990s were largely based on neoliberal assumptions that emphasise how increased internal liberalisation should, over time, lead to economic convergence via the efficient redistribution of resources and the creation of trade complementarities, or in political terms, greater autonomy to negotiate internationally via the pooling of sovereignty. Yet this has not occurred in many places, including the Caribbean, where structural asymmetries and accentuated levels of economic divergence are increasingly evident. Consequently, as liberalisation has not delivered the expected gains, much of the political will has drained from the traditional integration process - such as the 'pausing' of the Caribbean Single Market and Economy (CSME) - and actors have looked elsewhere for alternatives. ${ }^{9}$

Second, much of the literature, drawing - whether explicitly or implicitly - on constructivist insights, emphasises the socially and ideationally constructed nature of regions: although they are traditionally thought of as being communities of states underpinned by formal institutions - and, in many cases, this is exactly what they are - there is normally much more taking place. Recognising this has many analytical consequences. One is that simply looking at the formal constitution of a region - the extent of its institutions or legal mechanisms - emphasises form over content; simply because it exists constitutionally, it does not automatically follow that it 
either operates effectively or, crucially, that key actors perceive that it does. As such, we may well miss more important deeper dynamics, including the decay of institutions and their ultimate decline. We also neglect the more diffuse elements of regional projects, of which one is the increased importance of non-state actors in constituting and driving forward more informal processes of integration (Brazilian migration to the Guianas being a good example).

Third, the sheer complexity of contemporary regionalism - in terms of both the number of regional projects, and wide variety of actors with a stake in them - is quantitatively and qualitatively different to previous eras. We have more regions today, with different rationales, operating at different levels, and many societies (or parts of societies) are enmeshed within them in highly complex, overlapping ways. Moreover, as some rise and others decline, the role that these regions play in the consciousness of key actors or the wider population waxes and wanes too. One particularly important effect is the way in which regionalism has, to some extent, become de-territorialised. Traditionally, regions encompassed groups with relatively fixed identities. For example, the Caribbean Community (CARICOM) was, at least in part, originally based on a particular shared understanding of (Anglophone) West Indianism, although in recent years that has been lost amidst the emergence of more insular identities, in part explaining the relative decline of the institution. ${ }^{10}$ However, today, regionness does not need to be geographically fixed: increasingly, such entities take many different forms, and overlap simultaneously within - and beyond - the same geographical space.

In Latin America and the Caribbean, Riggirozzi has shown how two distinct institutions - the Venezuela-led Bolivarian Alliance for the Peoples of our America (ALBA) and UNASUR - have both evolved separately, encompassing a different but overlapping membership, with distinct ideological rationales. ${ }^{11}$ Yet what they both have in common is an attempt to create new intersubjective identities by encompassing a wider membership beyond the traditional, Hispanic and Lusophone societies of Latin America, and also post-neoliberal or post-hegemonic projects that are about much more than simply trade liberalisation. Although she does not fully reject economic considerations, Riggirozzi argues that the terms of regional integration are being redefined as regional projects offer substantially divergent visions of what Latin Americanness should mean and how integration projects should respond to current challenges of global political economy ${ }^{\prime 2}{ }^{12}$ In a similar vein, Emerson emphasizes the contestation that is at the heart of regional development in Latin America. This in turn is shaped by the meanings that key actors share regarding the nature and purpose of regionalism, and this 'not only shapes their respective interests and identities, but also refashions the inter-subjective realm itself'. ${ }^{13}$ In practice, then, the very perceptions of the region are changing. This can refer to form - in that territories like the Guianas are increasingly being incorporated into a continent from which they have traditionally been alienated ${ }^{14}$ - but it can also refer to substance, which, in many ways is far more interesting and important, since the inter-subjective understandings that are shared by regional actors, especially those within Guyana, Suriname and French Guiana also change as their mental regional landscape is increasingly reconfigured by their engagement with Latin America in general, and Brazil in particular. 
This brings us to the question of hegemony, for contemporary regional developments in Latin America are not shaped without the deployment of power, and, in particular, Brazilian power. As a concept, hegemony is traditionally associated with the United States (US). In conventional Realist thought in IR, it refers to the capacity of a key state to fundamentally shape the rules of world order. This is crucial: hegemony is not simply a question of raw power, or of being the most powerful state; it is about being able to both determine the rules of the game, and enjoy the acquiescence of other key states, with hegemonic power refracted through key global institutions. A major preoccupation of many analysts in IR and International Political Economy (IPE) has been the extent to which the relative decline of the US - which, although it remains the most powerful state, cannot reshape world order in its own image in the way it did in 1945 - implies that a degree of instability may subsequently ensue as challengers like China continue to upset the balance of power in the international system.

This issue does not primarily concern us here, since it refers to a wider debate about hegemony and world order playing out elsewhere. ${ }^{15}$ What is of interest, though, is the concept of hegemony itself, and, in particular, the idea of a 'regional' hegemon. Does this help us better understand the behaviour of Brazil in contemporary South America? In traditional realist terms, a regional hegemon is one which is able to dominate a particular space, advance regulations and rules in that space, and perhaps enjoy the benefits - and tribute - of its power from other states. ${ }^{16}$ In the past, the US has dominated the continent, and American initiatives have prevailed. However, the recent turn towards domestic-driven arrangements challenges this, and suggests that US power, in tandem with reconfigurations in the form and substance of its global power, may not be as salient as once was the case. Yet to what extent are regional institutions constructed in Brazil's image, and with what consequences, and does the notion of regional hegemony help us to better understand what is going on? It will be impossible to answer fully all of these questions in this paper, but four key points are worth noting at this juncture.

First, Brazil's role cannot simply be measured in the kind of language of raw material power that has historically accompanied debates about hegemony. If Brazil's increased influence over the region in general - and the Northern Amazonian space in particular - is anything, it results from the deployment of a subtle form of power, which is not necessarily always state-based, wielded by numerous actors and forces, and it not always easy to grasp. This is very much the kind of 'soft power' that Joseph Nye has written about extensively. ${ }^{17}$ Indeed, as Soreanu Pecequilo and Alves do Carmo have noted, 'both cooperation and power projection are viewed as purposes in the country's foreign policy agenda as a regional and global player'. ${ }^{18}$ Second, Brazilian influence is likely to be uneven: the way it manifests itself in the building of regional arrangements, economic investment, formal diplomacy, and, of course, more diffuse processes like migration of Brazilians and the attendant cultural expansionism, all play out in distinct and complex ways. In this sense, the effects of Brazil's attempts at 'consensual hegemony' are often ambivalent, ambiguous and partial: it has remained detached from certain regional developments, like ALBA, therefore acquiescing to alternative ideological arrangements rather than challenging them; it has been extremely active in forcing the pace of integration in others, 
such as the Southern Common Market (MERCOSUR); and underpinning most regional activity has been a firm preference for leading in areas that help it achieve its global ambitions, such as permanent membership of the UN Security Council. ${ }^{19}$ What is interesting about its pick-andmix approach to its neighbourhood is that no other Latin American country has sought to challenge it: this is, as Schenoni suggests, potentially surprising since it has both helped render Brazil's regional rise more successful than might otherwise have been the case, and, in turn, allowed it to further position itself as an emerging global power relatively free from local antagonism or competition. ${ }^{20}$ Of course, we might reasonably speculate that such acquiescence actually evinces the fact of its nascent hegemonic influence within the regional space.

Third, the consequences of Brazilian power for broader challenges to neoliberal norms are also likely to be contradictory. As Ban has argued in relation to the country's own development, it 'is neither a local replica of the Washington Consensus, nor a revolutionary departure' from it. ${ }^{21}$ The consequence of this is that, as the country is still charting its own development course in an experimental way, its external agenda will be intrinsically complex, with diffuse implications for other states within its sphere of influence. This is partly a reflection of what Dauvergne and Farias call its emergence as a 'global development power'. ${ }^{22}$ Brazil's internal and external orientations are increasingly and deeply entwined with each other: it is therefore guided by an outward approach that advocates and pursues development for the Global South as a whole, yet because this is partly a reflection of its own as-yet unfinished novel domestic developmental policy experiments, the intellectual, political and diplomatic consistency between the two is not always entirely clear. When combined with the two previous insights, Brazil's emerging regional hegemony can therefore be seen as both nascent and still unfolding: we can find clues as to its character and effects, but we cannot yet attribute to them the level of coherence that we might normally expect of a truly hegemonic power. Indeed, in a world where excessively state-centric understandings of hegemony are arguably not that useful anyway, it is perhaps even implausible that this would ever be the case (not to mention problematically teleological). Finally, tying all of this together, Brazil's evolving influence necessarily implies different things for different parts of the region. From the perspective of the Three Guianas, this will be quite particular. As a result, they provide both a fascinating prism through which to analyse new patterns of regional change in Latin America, and a distinctive one. It is to this empirical discussion that we now turn.

\section{New Patterns of Regional (Dis-) Integration in Latin America and the Caribbean}

The Three Guianas occupy a notably ambiguous position within what are increasingly complex processes of regional change. Although at present the process is subtle - and even almost imperceptible - they are gradually becoming disengaged from a Caribbean region with which they share a historical and cultural affinity, while simultaneously deepening their ties with new alliances in Latin America. This is largely a reflection of the changing pace of integration across the two overlapping regions: Caribbean mechanisms are in decline while new arrangements located on the continent are proceeding at a ferocious pace. But it is also a function of both 
their unique geographical location between the Amazon rainforest and the Atlantic Oceanboth of which are traditionally significant barriers to cross-border engagement, but which in the case of the former, has become more permeable - and their ties with Brazil that are becoming progressively more important. We deal with the question of Brazil in a subsequent section; as a prelude, we substantiate the claim regarding emergent patterns of regional integration and dis-integration, and discuss how the Guianas fit into these configurations.

All three territories are considered to be contiguous with the wider Caribbean because of their similar social structures and a broadly shared history of colonialism. Although French Guiana did not experience sugar slavery in quite the same way as its neighbours and the wider region, all three were essentially implicated in the same colonial processes that shaped the island Caribbean. Under colonial rule, efforts were made - particularly by the British - to bring separate territories together, but British Guiana (as Guyana then was) stood alone. Geographical apartness, the size of the territory compared to neighbouring islands, IndoGuyanese concerns about associating with largely Afro-Caribbean nations, and later tensions with the British over independence (attained in 1966) were all factors that limited Guyana's engagement. However, once independence was achieved, Guyana set aside its previous concerns and its role within the Caribbean became more influential - first within the Caribbean Free Trade Association (CARIFTA) and later within CARICOM. Overall, however, CARICOM's progress towards deeper integration has been disappointing: since 2011, the key component of neoliberal-era integration, the Caribbean Single Market and Economy (CSME) has been effectively dead in the water, and the sense is of an increasingly terminal pattern of decline. Further, as one of few countries with goods and natural resources to sell, Guyana has become frustrated by the limited level of intra-Caribbean trade: despite talk of the need for deeper integration and the potential benefits that could accrue (Stabroek News, July 1, 2013), the importance of CARICOM to Guyana is not as great as it once was, or indeed as it could be if there were genuine commitment to the integration process.

In officially Dutch-speaking Suriname, meanwhile, formal engagement with Caribbean regional institutions has been more recent and more hesitant, largely because of the different historical, cultural, and linguistic influences of the country. Suriname was the first nonAnglophone country to join CARICOM (in 1995; it had been an observer since 1982), but the move was not universally welcomed. Supporters felt it was important in advancing the decolonization process, reducing dependence on The Netherlands, and improving competitiveness and access to international donor financing, but many in the local business class were worried about greater economic liberalisation and competition. ${ }^{23}$ Indeed, the impact of membership has been mixed: according to the Inter-American Development Bank (IDB), Suriname's macro-economic environment has stabilised, but a number of barriers in trade, labour markets, financial services, and other sectors remain. ${ }^{24}$ In addition, because Suriname is not part of the Commonwealth it remains somewhat distant from the region as a whole. From Suriname's perspective the main advantage of belonging to CARICOM is not its market, but rather membership itself which enhances the country's place on the regional stage, as well as providing a stable link to the European Union (EU). 
Meanwhile, the position of French Guiana is quite different to its neighbours, with only a very limited level of integration with the wider Caribbean. This has a lot to do with its status: as a French Département d'Outre-Mer or French Overseas Department (DOM) its key institutional, financial and trading relationships are with France and the EU more broadly. It is also much smaller in population terms - a third the size of Guyana, and half that of Suriname - but it also much wealthier, with GDP per-capita four or five times higher, due to metropolitan subsidies and its status, essentially, as an offshore centre for European space exploration (echoing its colonial history as an offshore penal colony). Links with neighbours are therefore minimal: there are no direct flights to independent islands, and even connections to Martinique and Guadeloupe, the other DOM in the Eastern Caribbean, are limited.

So, overall, Guyana has the strongest ties to the Caribbean, and has established itself as an important actor in West Indian politics and diplomacy. Suriname's influence has grown in recent years but barriers of both language and politics - not least the questionable governance of President, and former military dictator, Desiré Delano ('Desi') Bouterse - remain that prevent its full integration, while French Guiana is almost entirely separate. However, the glacial pace of integration within CARICOM has meant that even Guyana is wondering whether the region remains the best forum to further its interests.

These doubts come at a time when both Guyana and Suriname are engaging actively on the continent, with UNASUR, the Community of Latin American and Caribbean States (CELAC) and MERCOSUR. The first two groupings - and particularly UNASUR - have the greatest potential for cooperation. Established in 2008, UNASUR has an explicit mandate to bring the region closer together, primarily via infrastructural development. Other initiatives include creating a single market by the end of the decade; promoting regional security; improving local competitiveness; free movement of people and a common passport; and, increasingly, attempts to ameliorate access to social goods such as healthcare. ${ }^{25}$ Because of its clear policy agenda, ambitious attempts to transcend narrow neoliberal regional settlements of the past, a deepening institutional structure, and substantial funds supporting it, it is quite plausible that UNASUR's evident attractiveness will lead to it becoming the primary regional interlocutor for Guyana and Suriname. As for CELAC (inaugurated in 2011) there has been much discussion about it becoming the future driver of a more intense process of hemispheric, as opposed to simply regional, integration. ${ }^{26}$ However, so far little has been achieved: there is no central organising agenda or series of themes underpinning its purpose beyond vague 'political dialogue', nor is there even a permanent secretariat. In 2013, the Caribbean secured a seat as the fourth member of CELAC's governing 'Troika', to be occupied by whichever country holds CARICOM's rotating presidency; it remains to be seen whether this will fall prey to the infighting that has traditionally blighted attempts to achieve a common Caribbean position on even the most simple of issues. For both organisations, then, the potential is undoubtedly there, although time will have to pass before a real South American future for Guyana and Suriname becomes fully apparent. 
For French Guiana, regional isolation continues: neither the territory itself nor France enjoys membership of UNASUR or CELAC, both of which have sought to transcend 'imperialist' relationships, also consciously excluding the US. Paris has nonetheless tried to afford local actors in the DOM more leeway to engage in diplomacy with regional states and institutions. ${ }^{27}$ It is the Association of Caribbean States (ACS) in which this has moved furthest, but arguably this institution has the most to lose from the development of CELAC undermining its rationale. In any case, French Guiana has not really taken advantage of these opportunities, unlike Guadeloupe and Martinique which have gained Associate Membership of both the ACS the Organisation of Eastern Caribbean States (OECS) and are seeking a similar status within CARICOM. Reticence on the part of French Guiana is due to: differences in the nature and desires of the local political class in Cayenne versus Fort-de-France (Martinique) and BasseTerre (Guadeloupe); relative differences of importance in the roles played by the DOM within France's own strategic global assessment; and relatedly, the fact that French Guiana borders Brazil, which, as will be shown is an infinitely more critical diplomatic partner for Paris than other regional groupings in the Caribbean.

In terms of the Guianas' bi-lateral relations in South America, Venezuela has been a key partner - although again this does not really apply to French Guiana. The economic relationship, particularly the PetroCaribe initiative, has been very important. PetroCaribe was launched in 2005 and provides budgetary and development support to a number of countries in Latin America and the Caribbean, along with cheap oil for which only a percentage has to be paid up front, with the remainder transferred into a soft loan. The full cost of the oil can then be deferred for a period of 25 years at a concessionary interest rate of around one percent. ${ }^{28}$ Guyana joined PetroCaribe back in 2005 and receives about 50 percent of its oil supplies via the arrangement. There have been several related benefits, including the cancellation of some of Guyana's debt and a more general growth in trade flows. Suriname has also benefitted from its PetroCaribe link. Corrales and Penfold estimated that total Venezuelan aid to Suriname in 2006 was somewhere between one hundred and three hundred million US dollars. ${ }^{29}$ However there are real concerns about the program's sustainability, in part because of Venezuela's economic problems and the weakening position of President Nicolas Maduro. Also, the recent reigniting of the long-term border dispute between Guyana and Venezuela over the former's claim to five-eighths of Guyana, comprising all lands west of the Essequibo River, which are rich in natural resources, as well its exclusive maritime zone, has seriously strained relations; and although Venezuela has strengthened ties with Suriname in an attempt to offset the problems with Guyana, the underlying vulnerability of the economic model which Venezuela sustains is clear to see.

In sum, the broad overlapping regional space between the Caribbean and Latin America is today in a state of flux. New arrangements are emerging in the latter just as existing ones stagnate in the former, and continental change is progressively encompassing, if not all Three Guianas then certainly Guyana and Suriname, and therefore reshaping the broader Amazonian space that they share with Brazil and Venezuela. This is hardly surprising: the ambition of UNASUR, in particular, and the more dynamic and rewarding forms of cooperation that it 
portends is of a different order to the unmet expectations, for Guyana, and the degree of suspicion and linguistic difference, on the part of Suriname - which came late to membership that has characterised their relations with CARICOM. However, casting a long shadow over the contours of these developments is the emerging regional hegemon, Brazil. For the Guianas, its role, both formal and informal, is crucial; it is to such a discussion that we now turn.

\section{Brazilian Hegemony in Latin America?}

Brazil's foreign policy towards its neighbours first came into strong focus at the beginning of the $20^{\text {th }}$ century during the tenure of Baron of Rio Branco as head of the Ministry of External Relations (1902-1912). He emphasised good relations, but there was also recognition that Brazil should not be seen to be taking a leading role and that Brazilian interests were somewhat different to those in Hispanic Latin America. ${ }^{30}$ As Burges suggests, 'Brazil lacks a history of conquest or imperial domination' ${ }^{31}$ Within this framework of ideas an entente cordiale policy with Argentina and Chile was developed, which later evolved into a Pacifist Treaty, also known as the ABC Treaty, between the three countries. ${ }^{32}$ Although the agreement broke down in 1923, the ideas of 'Pan-Americanism' with Brazil as a pro-active interlocutor continued to be important over the next two decades culminating in the creation of the Organisation of American States (OAS) in 1948. Brazil's relations with Latin America gained new prominence with Operation Pan America in 1958, which led to the establishment of the IDB. Two years later, the Latin American Free Trade Association was created, but for Brazil this was of limited benefit due to it focusing heavily on domestic economic development through Import-Substitution Industrialisation (ISI), and the later inward-looking nature of the military governments that ruled Brazil between 1964 and 1985. Indeed, in contrast to much of the wider region - and Argentina, notably - the specific nature of Brazil's experiment with ISI is considered to be a large part of the explanation for its subsequent economic success in the contemporary period.

With respect to post-colonial Guyana and Suriname this meant that Brazil not only monitored the emergence of leftist nationalist governments but was also wary of US (and English or Dutch) interference. ${ }^{33}$ Since the return of democracy, there has certainly been a refocusing on the regional dimension of Brazilian foreign policy, but it has neither been clear nor consistent. ${ }^{34}$ Parallels can be drawn with earlier attitudes that Brazil should be cautious in taking an obviously leading role. The country's foreign ministry (Itamaraty) has made significant efforts to strengthen Brazil's credibility in foreign-policy making but has been wary of pushing for a dominant role. ${ }^{35}$ The watch-word for Brazil remains multilateralism, and perhaps more particularly 'reciprocal multilateralism'. As Cervo argues, the concept involves two presuppositions: 'the existence of rules to govern the international order, without which the power disparity will prevail in favor of the great powers; and the joint formulation of these rules, so that they will not favor the interests of some to the detriment of the interests of others' ${ }^{36}$ These ideas appear to undermine the legitimacy of hegemonic leadership, and they apply equally to Brazil as any other country. Further, there is only limited evidence to suggest 
that other countries are prepared to embrace Brazil as the leading force in the region (with acquiescence of rivals another key determinant of hegemony).

In order to provide a greater degree of foreign policy coherence at the regional level, Brazil has over the last two decades or so placed more emphasis on South America, as opposed to Latin America as a whole. This marginalises Mexico and a number of other countries with close ties to the US, and in turn provides Brazil with a group of regional partners that share similar views on a range of domestic and international issues. Within this narrower regional context Itamaraty has promoted Brazil as the hub of the continent. ${ }^{37}$ This began under the presidency of Fernando Cardoso and was later extended by Lula who greatly increased Brazil's diplomatic representation in South America, even though ${ }^{38}$ not all embassies were fully staffed. ${ }^{39}$ Argentina, for good or ill, has always been the key partner, but regional initiatives like MERCOSUR, UNASUR, and the Integration of the Regional Infrastructure of South America (IIRSA), which will be considered below, are important. As Burges suggests 'the goal is to make South America a vibrant market for Brazilian products and a source for the energy resources that the country's economy needs' ${ }^{40}$ The importance of South America is already clear in that around 80 percent of Brazil's foreign direct investment (FDI) is concentrated there. ${ }^{41}$

However, even this focus on South America has been undermined by several factors. First, Lula's South-South Strategy (prioritising Africa and Asia) diluted the relative importance of South America. ${ }^{42}$ Second, the fractious and differentiated nature of South American politics with countries such as Colombia (via the Pacific Alliance bloc), Venezuela, Bolivia, as well as Argentina promoting their influence and interests means that Brazil is not 'the undisputed leader or representative of the continent'. ${ }^{43}$ Third, Brazil is apprehensive about 'sacrificing its national economic autonomy to regional formats'. ${ }^{44}$ Fourth, bilateral relations are often preferred. Fifth, it is not clear that 'the nation is willing to be responsible for the burdens of the leadership for the process of regional integration' ${ }^{45}$ One element of this, as Burges notes, is that Brazil has shown 'its unwillingness to engage in sustained expenditure to gain leadership of other countries'. ${ }^{46}$ Sixth, since Dilma Rousseff became president in 2011 there has been 'a waning in the political dimension of Brazil's approach to the region'. ${ }^{47}$

Overall, Rousseff's Presidency has been marked by continuity with Lula's agenda. As Dauvergne and Farias note, its vision has increasingly moved well beyond just Latin - or even South - America to the Global South as a whole. Brazil is, they argue, 'focusing on forming and leading coalitions of developing states to strengthen shared values and normative commitments' ${ }^{48}$ Indeed, in a series of speeches throughout her first term, Rousseff continually reiterated her support for: multilateral solutions to global problems; the unity of the Global South, with Brazil playing a key mediating role that allowed it to cut a distinctive path between the developing world and the North; a continued commitment to the development of the poorer parts of the world; and, indeed, to a deepening of South American integration free from external interference. However, as a report by the Council on Hemispheric Affairs noted as she acceded to power, there were a series of emerging contradictions facing the country: its nascent hegemony within South America, and, indeed, the desire of its policy elite to begin 
shaping global agendas more forcefully were both constrained to some extent by problems of border security and wider geopolitical instability in the region as a whole. ${ }^{49}$ As a consequence, Rousseff has sought to develop an active agenda of outward diplomatic expansion - for example, by hosting the 2014 BRICS Summit and emphasizing the importance of both the grouping and Brazil's role within it - while also engaging in an arguably more ideological foreign policy than her predecessor, in the sense that she has remained silent about destabilizing developments elsewhere in the region (such as the increasingly painful dénouement of the Chavez/Maduro experiment in Venezuela), or, indeed, globally (such as Russia's intervention in Crimea). She has also been weighed down early in her second term by the Petrobras corruption scandal: this clouded her 2014 re-election campaign, ${ }^{50}$ and coincided with a marked slowing down of Brazil's economy as the growth rate, after a decade of expansion ended when the growth rate collapsed to 0.1 per cent.

In sum, while regional integration remains important for Brazil, including within the context of promoting its economic development via trade and investment, the country's approach is constrained by its own circumspection and self-interest on the one hand and complex regional - and even global - dynamics on the other. As will be seen in the next section, the wider approach to South American integration on the part of Brazil has important ramifications for the Three Guianas - and the Amazonian space - now and in the future.

\section{Brazil and the Reshaping of Northern Amazonia}

The emerging relationship between the Guianas and an increasingly influential Brazil embodies formal material and diplomatic dimensions, as well as more diffuse, informal ones. At present, their consequences are not fully understood: this is partly due to the fact that the processes of change are relatively novel, aided by both Brazilian expansion and rapid resource-led growth in the Guianas, better links, and the increasing permeability of an Amazon rainforest which was traditionally a largely impenetrable barrier. Moreover, the relationship is developing in an experimental and tentative fashion: different elements can have simultaneously positive and negative consequences for Guyana, Suriname and French Guiana individually, and they are even potentially becoming locked into a competitive race with each other for Brazilian investment. The most pressing worry, particularly in Georgetown and Paramaribo (the capital of Suriname), is that something of a silent colonization may occur as these trends intensify. In this section we explore these shifts by focusing on three interlinked issues: intensified diplomacy, both historically and in the present; infrastructural development; and increased migration.

Ties between Brazil and the Guianas were first established after the former's development of the Amazon Basin in the late 1960s. The primary focus at that time was on Guyana, which had just secured its independence, and its territorial dispute with Venezuela. Brazil was concerned about the potential instability the dispute might cause and consequently strengthened relations with Guyana. This culminated in the joint Brazil-Guyana Commission for Economic Cooperation in $1971 .^{51}$ However, Guyana's move towards 'Cooperative Socialism' under Forbes 
Burnham and Guyana's wariness of getting too close to Brazil's military regime meant that relations cooled. Brazil's anxiety over leftist policies was later seen in relation to the military regime of Desi Bouterse in Suriname. Brazilian Minister of External Relations Ramiro Saravia Guerreiro considered the presence of Cuban advisors in Suriname (along with the December 1982 murders of 15 prominent critics of the Bouterse regime) as direct threats to Brazil's security. ${ }^{52}$ In response, Brazil used 'both the carrot and the stick' to encourage Suriname to move away from Cuba and moderate its rhetoric. ${ }^{53}$ It sent troops to the Suriname border, but also in April 1983 General Danilo Venturini, Brazil's Minister for Land Affairs, unexpectedly visited Paramaribo and promised to equip and train the Surinamese National Army. Later that year several economic cooperation agreements were signed between the two governments. ${ }^{54}$ A similar rapprochement was happening with Guyana - prompted by Guyana's worsening economic situation and the decision of Brazil's military regime to return the country to civilian rule. $^{55}$

In more recent times bilateral relations have been generally more positive. As was mentioned previously, Brazil has been developing strategic partnerships with other countries of the South and strengthening its position in the Western Hemisphere. As Montoute argues 'economic diplomacy is ... the main thrust of Brazilian foreign policy, pushing them to search for new markets, additional energy supplies and diversification of trade partners'. ${ }^{56}$ For Guyana, better relations could provide a tremendous fillip to its economy. In an attempt to expand economic links a number of initiatives have been taken. For example, in 2003 a partial abolition of visas was agreed; in 2009 a new border-crossing was established when a bridge was built over the Takutu River; also in 2009 the Guyana/Brazil Frontier Committee was created to enhance relations of the frontier regions; and in February 2013 a joint Working Infrastructure Group met for the first time to discuss a series of projects to aid economic integration, including hydropower sites in the Middle and Upper Mazaruni and upgrading the important LindenLethem road that links the Brazilian communities of the State of Roraima and Western Amazonas with Guyana. Progress on these projects has been slow, and indeed some of these have been talked about for many years. Nevertheless, in August 2014, Brazil once again committed both politically and economically to them. ${ }^{57}$

Relations between Suriname and Brazil have also intensified in recent years - a high point being the visit of President Lula to Suriname in December 2004. Afterwards, high-level bilateral contacts have resulted in treaties on agriculture, education, public health care, infrastructure, and defence and security. ${ }^{58}$ In November 2012, Suriname's Foreign Minister Winston Lackin opened the Consulate of Suriname in Belém, with jurisdiction over the states of Pará, Amapá, Amazonas and Maranhão. ${ }^{59}$ For French Guiana, as with Guyana, improving transportation links has been important. Indeed, French Guiana was the first of the Guianas to announce the building of a land border to Brazil in 1997. After many delays it was completed in 2011, and commissioned in $2013 .{ }^{60}$ As Jacobs notes, the connection between Saint-Georges-de-l'Oyapock and Oiapoque on the two sides of the river represents not only 'the first road link between France and Brazil' but also 'the first overland connection between the European Union and the Americas'. ${ }^{61}$ Moreover, Cayenne's relationship with Brazil is unusual in that it is largely 
overshadowed by high politics with Paris: in particular, the two countries have significant cooperation agreements in the fields of defence and arms procurement, intensified by a large defence pact signed between Presidents Lula and Sarkozy in 2008.

Less official, but probably even more important, are the relations between Brazil and the Three Guianas in relation to population movements across borders. The lack of border security makes it easy for Brazilians to move to the Guianas. The estimates of Brazilians living in Suriname vary widely: from 4,000 to 40,000 , and these can change quite rapidly. Scholars and government officials estimate that two thirds of a total of 20,000 miners are garimpeiros from Brazil or other South American or Caribbean countries; many of them stay for only a few months). In Paramaribo, a few communities near the city centre have developed into a 'Brazilian neighbourhood', locally known as 'Klein Belem' (Little Belem or Belenzinho). The Suriname census of 2004 stated that at most 23,000 Brazilians were living in Suriname, out of a total population of around half a million. According to Jose Cardoso Neto, president of the Cooperation of Garimpeiros in Suriname, there were approximately 13,000 Brazilians, mostly men, in Suriname at the time of the census. Cardoso Neto explained that most of these men came without their families and stayed for two months on average. ${ }^{62} \mathrm{He}$ added that 'a sizable number of Brazilian women have married a Surinamese man, thus making them Surinamese nationals' ${ }^{63}$ Mining not only attracts garimpeiros, but also shop, bar, and brothel owners, sex workers, cooks, and commercial gold buyers. ${ }^{64}$ Surprisingly, the 2012 census reported that 0.9 percent of the population consisted of Brazilian nationals (2,902 people) but this figure surely understates the everyday population since large numbers of people will be either transient or undocumented. ${ }^{65}$ Soon after his re-election in May 2015, President Bouterse announced that the country was in recession. ${ }^{66}$ The worldwide drop in the price of oil and gold has had a tremendous effect in an economy largely based on the exploitation of natural resources. A related question, therefore, is how this economic downturn will affect the gold industry and the migration of Brazilian garimpeiros, also given the fact that the Brazilian economy is experiencing a downturn as well.

The easy movement across borders is not a new phenomenon in the region as Amerindians, and to a lesser degree Maroons, traditionally have moved across the contagious areas of the Guianas, Brazil, and Venezuela. ${ }^{67} \mathrm{~A}$ new development is the growing Brazilian cultural influence: in the late 1990s, satellite dishes began to appear in the interior, enabling Brazilians but also local residents to watch Brazilian television. ${ }^{68}$ Also new is that the Brazilian immigrants do not form a community anymore, like the 'old' immigrants from China, India, or Indonesia who settled previously. Rather, the Brazilians form a network 'to emphasise the relatively feeble and instrumental character of the ties they maintain with one another' ${ }^{69}$ The influx of garimpeiros and accompanying Chinese and Brazilian small businesspeople has transformed the social structure and culture of the interior, which has long been populated primarily by Indigenous peoples and Maroons. Despite collaboration between Brazilians and Maroon smallscale gold miners, ${ }^{70}$ the new situation provokes conflict and in 2009 even a major outbreak of violence. In the village of Papatam Kondre, the murder of a Maroon by a Brazilian, which arose from a personal dispute over a debt 'for smuggling Brazilians,' led to arson of shops, a hotel, 
houses and cars, assault, rape, and robbery (including in the neighbouring small town of Albina), by 'hundreds' of Maroons. The mayhem resulted in the death of a Brazilian, thirteen wounded and twenty official charges of rape. More than one hundred Brazilians and Chinese were evacuated to Paramaribo. Almost a year later, four Maroons were convicted to jail terms ranging from one to four years. ${ }^{71}$

There is also the flow of Brazilians into Guyana especially into the gold and diamond mining industries, and increasingly into the establishment of nightclubs and restaurants in Georgetown. In total approximately 70,000 Brazilians live in Guyana, about nine per cent of the population. ${ }^{72}$ The presence of illegal Brazilians is a continuing concern. For example, in 2001 Guyana's Ministry of Foreign Affairs embarked on a (short-lived) 'regularisation campaign' aimed at arresting Brazilians illegally living in the country; while in 2009 the Guyana Gold and Diamond Miners Association asked the government to take action against illegal Brazilian miners who were allegedly having a negative impact - both economically and environmentally - on the industry. There have also been broader concerns about drug and gun smuggling across the border. However the authorities of each country have never addressed these concerns in any systematic way. French Guiana has also experienced a massive influx of foreign migrants, and, although good data is hard to come by, there could be as many as 15,000 Brazilians mining gold in French Guiana today. This new demographic reality has caused a social, economic and political crisis. The influx of migrants in a shrinking economy with a high level of unemployment has led to socioeconomic tensions, conflict and even violence, particularly regarding illegal migrants, the majority being Brazilians. The growing migrant population also has an impact on state finances as the population increase demands major investments in public services, such as health care and education. ${ }^{73}$

Despite these quite significant formal and informal ties, gaps in the present relationships remain. One example is the lack of an all-weather road from the Takutu Bridge to Guyana's coast. As Sanders argues 'until the [...] road is constructed, Brazil still cannot use Guyana effectively for transporting exports from its northern region' ${ }^{74}$ Further, trade flows are relatively small at about two per cent of Guyana's total trade. ${ }^{75}$ For Suriname, Brazil is not among its seven most important export or import partners. ${ }^{76}$ Indeed, in a report published in March 2014 by the EU-funded Caribbean Export, it was argued that both Guyana and Suriname are failing to take advantage of trade opportunities with Brazil - largely because many of their most competitive products are not included within existing agreements, and that major infrastructural deficiencies (high energy costs and poor road systems) remain in place. Further, the report noted 'private sector apathy' and that most stakeholders had indicated that previous initiatives to boost trade ties with Brazil had 'little credibility'. In short, it was felt that there was a general lack of public sector commitment to follow through on already agreed plans. ${ }^{77}$ Meanwhile, relations between French Guiana and Brazil are to some extent constrained because they are overlaid by the 'high politics' of diplomacy between Paris and Brasilia. The two countries, in fact, have a formal strategic alliance and France has been a vocal advocate of Brazil's attempt to secure a permanent seat on the UN Security Council. One 
source of tension, though, remains the (security of the) highly porous borders of the Amazon rainforest.

As well as the bilateral links, multilateral links incorporating Brazil and the Three Guianas are growing in importance. An early example of this was in 1978 when the Amazon Cooperation Treaty (ACT) came into force. Eight countries (Bolivia, Brazil, Colombia, Ecuador, Guyana, Peru, Suriname, and Venezuela) committed themselves to the development of the interior: the exploitation of raw materials and the building of physical infrastructural projects. The plan was to establish or improve land, water, air, and telecommunication links. ${ }^{78}$ Later sustainability of the Amazon forests became a focal point. According to the countries involved, the Pact was a platform for joint discussions and projects and consequently a key step in continental integration. In 1995, the Amazon Cooperation Treaty Organization (ACTO) was created to support the Treaty, and a permanent secretariat was established in Brasilia in 2002.

An even more important influence on infrastructural development is IIRSA, which is currently under the auspices of UNASUR and its Infrastructure and Planning Council (COSIPLAN). IIRSA is a continental initiative by South American governments launched in 2000 and a vital geopolitical concern for Brazil. ${ }^{79}$ It aims to encourage 'open regionalism' and to 'strengthen a comprehensive insertion of South America in world markets' ${ }^{80}$ It does this by promoting projects in the sectors of transportation, energy and telecommunications, as well as regulatory measures to improve how these services are provided. ${ }^{81}$ The IIRSA Strategic Vision 2020 identifies nine development hubs, of which the Guianese Shield Hub has the most impact on development in the Guianas. The Guianese Shield Hub intends to link the Guianas with Brazil and Venezuela by developing key route-ways between the five countries. So, for example, the Arco Norte road project will create a link between Manaus and Boa Vista in northern Brazil, the capitals of the Three Guianas, and Amapá at the mouth of the Amazon River. While, next to the existing link between Boa Vista and Caracas, a new route is planned between the Venezuelan town of Ciudad Guyana and the mining town of Linden in Guyana and Paramaribo. Further, a range of infrastructure projects are being designed, including new hydro-electric power schemes, high voltage transmission lines, and industrial plants. Thus, these development plans will contribute to the integration of the three countries with the rest of the continent and will open the least affected stretches of the Amazonian rainforest to economic development. As Van Dijck argues, 'IIRSA's potential impact on the region's economic geography may be significant through its stimulus to investment, production, and trade. The Initiative may even induce the rise of new centres of economic gravity in the region' ${ }^{82}$ However, there are clearly also risks of such development. In his analysis Van Dijck considers particularly the 'spatial impact of roads' and how an expanding road network could exacerbate deforestation; a large problem already across the Guianas. Ultimately Van Dijck argues that 'the overall impact of new roads on development is hard to assess ex ante' ${ }^{83}$ Thus IIRSA/COSIPLAN could bring about dramatic changes to the Guianas and their relationship with Brazil more generally. However, as we have seen rhetoric often exceeds reality, and time will only tell whether there is the necessary commitment and proper planning to fulfil the Initiative's promise. 


\section{Conclusion}

We began this article by focusing on Guyana's hosting of the 2010 UNASUR summit and the symbolism of this event; Suriname repeated the feat three years later. So it is clear from these acts of summitry that Guyana and Suriname are establishing an important presence beyond the Caribbean and into South America (although their smaller neighbour, French Guiana, less so). By drawing on the concepts of regionalism and hegemony, we have sought to show, firstly, how significant regional reconfigurations - whether through the rise of formal projects like UNASUR or CELAC, or via more subtle and diffuse perceptions on the part of key actors regarding the reshaping of regional spaces - are underway in Latin America and the Caribbean, and, secondly, that these are driven, in often ambiguous ways, by the distinctive character of Brazilian power and influence. Moreover, the Northern Amazonian space provides a unique and fascinating location in which to view these processes of change, which are occurring at a rapid pace with, as-yet, unknown implications.

But what is known? Empirically, the paper has sought to show that, amidst the decay of preexisting regional projects in the Caribbean, and the emergence of their more dynamic counterparts in Latin America, at least two of the Three Guianas are increasingly moving towards a continental destiny. Nonetheless, this process is far from finished or assured. Brazil's role in the Amazonian space that it shares with the Guianas is complex and at times contested, due to the numerous stakeholders that are involved and the consequent interlacing of official and more diffuse ways of exerting influence. ${ }^{84}$ Further, there are mixed views of Brazil in the three territories. Many believe that closer ties with Brazil will precipitate significant economic growth and development; while others fear that Brazil will come to dominate their economic networks, migration patterns, and infrastructural connections. So the verdict is still open as to whether Guyana, Suriname, and French Guiana will benefit unequivocally from the evolving hemispheric reconfigurations and Brazil's geographical proximity, but what is clear is that these countries are at the centre of some very interesting and potentially very important processes of regional and hemispheric change that could revolutionize the way they are seen within both South America and the Caribbean.

\section{Notes}

\footnotetext{
${ }^{1}$ Riggirozzi, "Regionalism through social policy."

${ }^{2}$ We should note here that the notion of the 'Three Guianas' is primarily a historical reference that we use for convenience to highlight the similarities between the three territories. In the colonial period, we could indeed have spoken of British Guiana (now Guyana), Dutch Guiana (now Suriname) and French Guiana (which is now a non-independent territory, the French Overseas Department of la Guyane). At one time it may actually have been proper to speak of Five Guianas, but both Portuguese and Spanish Guiana have experienced different destinies: the former is today the state of Amapá in Brazil, and the latter now comprises a large swathe of contemporary Venezuela.

${ }^{3}$ Gamble and Payne, "Introduction," 2.

${ }^{4}$ Hettne, "Beyond the 'New' Regionalism," 543.

${ }^{5}$ lbid.

${ }^{6}$ See, Hettne and Söderbaum, "Theorising Rise of Regionness"; and Hettne, "Beyond the 'New Regionalism."
} 
7 See, Gamble and Payne, "Introduction"; and Bowles, "Regionalism and Development."

${ }^{8}$ Hettne, "Beyond the 'New' Regionalism," 543.

9 Bishop, "Whither CARICOM?"

${ }^{10}$ See, Payne, The Political History of CARICOM; and Bishop and Payne, "Caribbean Regional

Governance."

${ }^{11}$ Riggirozzi, "Region, Regionness and Regionalism."

12 Ibid., 422.

${ }^{13}$ Emerson, "Art of the Region," 560.

${ }^{14}$ See, Hoefte, Bishop and Clegg, "Contemporary Development in 'Three Guianas'."

${ }^{15}$ For a classic overview of this debate, see: Strange, "Persistent Myth". For a more recent account, see: Layne. "This Time It's Real".

${ }^{16}$ See Mearsheimer, Tragedy of Power Politics.

${ }^{17}$ Nye. "Soft Power".

${ }^{18}$ Soreanu Pecequilo and Alves do Carmo. "Regional Integration and Brazil," 51.

${ }^{19}$ See, Burges. "Brazil's International Development Co-operation"; Krapohl, Meissner and Muntschick.

"Regional Powers as Leaders"; and Flemes and Wehner, "Drivers of Strategic Contestation."

${ }^{20}$ Schenoni, "Ascenso y hegemonía".

${ }^{21}$ Ban. "Brazil's liberal neo-developmentalism," 2.

22 Dauvergne and Farias. "The Rise of Brazil".

${ }^{23}$ Banks. "Integratie van Suriname".

${ }^{24}$ Drzeniek-Hanouz, Mia and Trujillo Herrera. Competitiveness of Selected CARICOM Countries, 28.

${ }^{25}$ Riggirozzi, "Region, Regionness and Regionalism"; and Riggirozzi, "Regionalism, activism, and rights."

${ }^{26}$ Kirton. "CARICOM's Engagement with Latin America."

${ }^{27}$ Mrgudovic. "Sovereignty in the French Pacific."

${ }^{28}$ Bryan, A. "Petrocaribe and CARICOM."

${ }^{29}$ Corrales and Penfold. Dragon in the Tropics.

${ }^{30}$ Bueno, Vigevani, and Ramanzini Júnior. "Latin American Integration."

${ }^{31}$ Burges. "Brazil as a bridge," 577.

${ }^{32}$ See, Lins. Rio Branco, 613; and Bueno, Vigevani, and Ramanzini Júnior. "Latin American Integration."

${ }^{33}$ Avila. "Em Defesa."

${ }^{34}$ Montero. Brazil: Reversal of Fortune.

${ }^{35}$ Burges. Brazilian Foreign Policy.

${ }^{36}$ Cervo. "Brazil and the world," 11.

${ }^{37}$ Vigevani and Ramanzini Júnior. "Latin American Integration."

${ }^{38}$ Soares De Lima and Hirst. "Brazil as an intermediate state," 30.

39 Burges. "Brazil as a bridge," 582.

${ }^{40}$ Burges. "Building a Global Southern Coalition," 1344.

${ }^{41}$ Gratius and Gomes Saraiva. "Continental Regionalism: Brazil's role," 3.

${ }^{42}$ Soares De Lima and Hirst. "Brazil as an intermediate state."

${ }^{43}$ Montero. Brazil: Reversal of Fortune, 175.

${ }^{44}$ Ibid., 165.

${ }^{45}$ Soreanu Pecequilo and Alves do Carmo. "Regional Integration and Brazil," 62.

${ }^{46}$ Burges. "Building a Global Southern Coalition," 1348.

${ }^{47}$ Gratius and Gomes Saraiva. "Continental Regionalism: Brazil's role," 6.

48 Dauvergne and Farias. "The Rise of Brazil," 903.

49 COHA. "Brazil and UNASUR".

${ }^{50}$ The Economist. "The Big Oily".

${ }^{51}$ Grant. "The Three Guianas."

52 Janssen. In Search of A Path, 120.

${ }^{53}$ Grant. "The Three Guianas," 329.

54 Janssen. In Search of A Path, 120- 121.

${ }^{55}$ Grant. "The Three Guianas."

${ }^{56}$ Montoute. "Emerging players in the Caribbean," 10. 
${ }^{57}$ Stabroek News. "Brazil recommits to Lethem road."

${ }^{58}$ De West. "Suriname intensiveert betrekkingen"; StarNieuws. "Braziliaanse missies voor."; StarNieuws.

"Verdrag Suriname Brazilië."; and StarNieuws. "In oktober gezamenlijke."

${ }^{59}$ StarNieuws. "Suriname opent consulaat."

${ }^{60}$ Granger. "As Guianas e o Brasil."

${ }^{61}$ Jacobs. "The Loneliness of the Guyanas."

${ }^{62}$ Hoefte. Suriname in the Twentieth Century.

${ }^{63}$ ABS. Censuskantoor, 26-7.

${ }^{64}$ De Theije. "Transnationalism in Surinam."

${ }^{65}$ Algemeen Bureau voor de Statistiek. "Definitieve resultaten".

${ }^{66}$ Lamé, "Net herkozen en Bouterse".

${ }^{67}$ See, Carlin and Mans. "Movement through time," 76-77; Simonian and da Silva Ferreira. "Brazilian Migrant Workers," 99.

${ }^{68}$ Van Stipriaan. "Maroons," 154-155.

${ }^{69}$ De Theije and Bal. "Flexible Migrants," 67.

${ }^{70}$ De Theije and Heemskerk. "Moving Frontiers in the Amazon," 13-19.

${ }^{71}$ StarNieuws. "Ook dit is geen Suriname."; StarNieuws. "Vijf mannen veroordeeld."; and Menke and Pérez. "Surinamese Strategic Culture," 23.

${ }^{72}$ Lloyd. "The unpaved road."

${ }^{73}$ Piantoni, Frédéric. L'enjeu migratoire, 9-11; and Simonian and da Silva Ferreira. "Brazilian Migrant Workers," 100-104; 110.

${ }^{74}$ Sanders. "French Bridge to Brazil."

${ }^{75}$ Guyana Bureau of Statistics. GDP \& trade statistics.

${ }^{76}$ Economywatch. Suriname Trade Statistics.

${ }^{77}$ Stabroek News. "Guyana, Suriname trade."

${ }^{78}$ Van Dijck. IIRSA Road Infrastructure Programme, 251.

${ }^{79}$ Gehre and Linhares. "Brazil and Guyana,"; and Silva and Silva. Relações Internacionais Brasil-Suriname.

${ }^{80}$ Van Dijck. "Troublesome Construction," 103.

${ }^{81}$ Carciofi. "Regional Public Goods."

${ }^{82}$ Van Dijck. "Troublesome Construction," 101.

${ }^{83} \mathrm{lbid} ., 111$.

${ }^{84}$ Dupeyron. "Perspectives on Mercosur Borders," 63.

\section{Bibliography}

Algemeen Bureau voor de Statistiek (ABS). Censuskantoor. Paramaribo: ABS, 2006.

Algemeen Bureau voor de Statistiek. Definitieve resultaten achtste algemene volkstelling. Paramaribo: ABS, [2012]. [Vol. 1.] http://www.statisticssuriname.org/index.php/statistieken/downloads/category/30-censusstatistieken-2012

Avila, C. F. Domínguez. "Em Defesa Da Democracia e do Interesse Nacional: O Brasil Diante do Interregno Kraag no Suriname (1991)." Textos \& Debates 1, no. 14 (2008): 41-66.

Ban, Cornel. "Brazil's liberal neo-developmentalism: New paradigm or edited orthodoxy." Review of International Political Economy 20, no. 2 (2013): 298- 331. doi: 10.1080/09692290.2012.660183. 
Banks, Helga. "Integratie van Suriname in de CARICOM in historisch perspectief 1973-2008:

Een moeizaam maar positiefproces". In His/HerTori: Tijdschrift voor Surinaamse geschiedenis en cultuur 2: 17-27.

Bishop, Matthew Louis. "Whither CARICOM?" In Re-mapping the Americas, edited by W. Andy Knight, Julián Castro-Rea and Hamid Ghany. Surrey: Ashgate Publishing Limited, 2014.

Bishop, Matthew Louis and Anthony Payne. "Caribbean Regional Governance and the Sovereignty/Statehood Problem", Waterloo: The Centre for International Governance Innovation Caribbean Paper, no. 8 (2010). Available at:

https://www.cigionline.org/sites/default/files/caribbean paper $80 . p d f$

Bowles, Paul. "Regionalism and Development after(?) the Global Financial Crises." New Political Economy 5, no. 3 (2000). doi: 10.1080/713687783.

Bryan, A. "Petrocaribe and CARICOM: Venezuela's Resource Diplomacy and its Impact on Small State Regional Cooperation." in The Diplomacies of Small States: Between Vulnerability and Resilience, edited by A. Cooper and T. Shaw, 143-159. Basingstoke: Palgrave Macmillan, 2013.

Bueno, C., T. Vigevani, and H. Ramanzini Júnior. "Latin American Integration: A Brazilian View." In Resilience of regionalism in Latin America and the Caribbean, edited by A. Pontigliano and J. Briceño Ruiz, 207-231. Basingstoke: Palgrave Macmillan, 2013.

Burges, S. "Building a Global Southern Coalition: the competing approaches of Brazil's Lula and Venezuela's Chávez." Third World Quarterly 38, no. 7 (2007): 1343-1358.

Burges, Sean. Brazilian Foreign Policy After the Cold War. Gainesville: University Press of Florida, 2009.

Burges, Sean. "Brazil as a bridge between old and new powers?" International Affairs 89, no. 3 (2013): 577-594.

Burges, Sean. "Brazil's International Development Co-operation: Old and New Motivations." Development Policy Review 32, no. 3 (2014): 355- 374. doi: 10.1111/dpr.12059.

Carciofi, Ricardo. "Cooperation for the Provision of Regional Public Goods: The lirsaCase." In The Rise of Post-Hegemonic Regionalism: The Case of Latin America, edited by Pia Riggirozzi and Diana Tussie. Heidelberg-London-New York: Springer, 2012: 65-80.

Caribbean News Desk, 2015. Venezuela dumps Guyana, turns to Suriname for rice under PetroCaribe deal, 16 October. Available at: http://caribnewsdesk.com/news/11168-venezuela-dumps-guyana-turnsto-suriname-for-rice-under-petrocaribe-deal 
Carlin Eithne B. and Jimmy Mans. "Movement through time in the Southern Guianas:

Deconstructing the Amerindian kaleidoscope." In In and out of Suriname: Language, mobility and identity, edited by Eithne B. Carlin, Isabelle Léglise, Bettina Migge, and Paul Tjon Sie Fat. Leiden: Brill, 2014: 76-100.

Cervo, A. "Brazil's rise on the international scene: Brazil and the World." Revista Brasileira de Política Internacional 53, (2010): 7-32.

Corrales, Javier, and Michael Penfold. Dragon in the Tropics: Hugo Chavez and the Political Economy of Revolution in Venezuela. Washington, DC: The Brookings Institution, 2011.

COHA. "Brazil and UNASUR: Regional Security and the Nation's World Standing in the Era of Rousseff's Rule". Washington, DC: Council on Hemispheric Affairs, 2 November 2010. Available at: http://www.coha.org/brazil-and-unasur-regional-security-and-the-nation\%E2\%80\%99sworld-sanding-in-the-era-of-rousseff\%E2\%80\%99s-rule/

Dauvergne, Peter and Déborah BL. "The Rise of Brazil as a Global Development Power". Third World Quarterly 33, 5 (2012): 903-917.

De Theije, Marjo. "Transnationalism in Surinam: Brazilian Migrants in Paramaribo." In Caribbean Transnationalism: Migration, Pluralization, and Social Cohesion, edited by Ruben Gowrichard, 117-135. Lanham: Lexington Books, 2006.

De Theije, Marjo and Ellen Bal. "Flexible migrants. Brazilian gold miners and their quest for human security in Surinam". In, A world of insecurity: Anthropological perspectives on human security, edited by Ellen Bal et al. London/Sterling, Virginia: Pluto Press, 2010.

De Theije, Marjo and M. Heemskerk. "Moving Frontiers in the Amazon: Brazilian Small-Scale Gold Miners in Suriname." Revista Europea De Estudios Latinoamericanos y del Caribe 87 (2009): 5-25.

De West. 2009. "Suriname intensiveert betrekkingen met Brazilie." 16 September.

Drzeniek-Hanouz, M., I. Mia and E.Trujillo Herrera. Measuring the Competitiveness of Selected CARICOM Countries: The Findings of the Global Competitiveness Index 2009-2010. Washington DC: Inter-American Development Bank (No. IDB-DP-166), 2009.

Dupeyron, B. "Perspectives on Mercosur Borders and Border Spaces: Implications for Border Theories." Journal of Borderland Studies 24, no. 3 (2009): 58-67.

Economywatch. 2015. Suriname Trade Statistics, Export Statistics, Export Partners and Products, Import Statistics, Import Partners and Products. 17 March. Available at http://www.economywatch.com/economic-statistics/Suriname/Trade Statistics/ (accessed 29 April 2015). 
Emerson, R. Guy, "An Art of the Region: Towards a Politics of Regionnness." Third World Quarterly 19, no. 4 (2014): 559-577.

Flemes, Daniel and Leslie Wehner, "Drivers of strategic contestation: The case of South America." International Politics 52, no. 2 (2015): 163-177.

Gamble, Andrew and Anthony Payne, ed. Regionalism and World Order. New York: St. Martin's Press, 1996.

Gamble, Andrew and Anthony Payne. "Introduction: The Political Economy of Regionalism and World Order." In Regionalism and World Order, edited by Gamble, Andrew and Anthony Payne. New York: St. Martin's Press, 1996.

Gehre, Th. and E. Linhares. "Brazil and Guyana: From Distant Neighbors to Potential Partners." Mural Internacional 3, no. 2 (2012): 16-23.

Granger, S. "As Guianas e o Brasil: da Contenção à Continentalização, ou Perigos e Vantagens de uma Interface Caribenha e Europeia." Acta Geográfica (Boa Vista) 7, no. 15 (2013): 19-38.

Grant, C. "The Three Guianas: Their External Relations." In Intervention, Border and Maritime Issues in CARICOM, edited by K. Hall and M Chuck-A-Sang. Kingston: lan Randle Publishers, 2007.

Gratius, S. and M. Gomes Saraiva. "Continental Regionalism: Brazil's prominent role in the Americas." CEPS Working Document 374, February 2013. Available at http://www.ceps.eu (accessed 18 September 2014).

Guyana Bureau of Statistics. 2014. GDP \& trade statistics. Available at www.statisticsguyana.gov.gy/ (accessed 18 April 2014).

Hettne, Björn. "Beyond the 'New' Regionalism." New Political Economy 10, no. 4 (2005): 543. doi: $10.1080 / 13563460500344484$.

Hettne, Björn and Fredrik Söderbaum. "Theorising the Rise of Regionness." New Political Economy 5, no. 3 (2000). doi: 10.1080/713687778.

Hoefte, Rosemarijn. Suriname in the Long Twentieth Century: Domination, Contestation, Globalization. London: Palgrave Macmillan, 2014.

Hoefte, Rosemarijn, Matthew Louis Bishop and Peter Clegg. "Still Lonely After All These Years? Contemporary Development in the 'Three Guianas'." Caribbean Studies 43, no. 1 (2015). Forthcoming. 
Jacobs, Frank. 2012. "The Loneliness of the Guyanas." Opinionator: The New York Times, January 16. Available at http://opinionator.blogs.nytimes.com/2012/01/16/the-loneliness-ofthe-guyanas/? $r=2$.

Janssen, R. In Search of A Path: An Analysis of the Foreign Policy of Suriname from 1975 to 1991. Leiden: KITLV Press, 2011.

Kirton, Mark. CARICOM's Engagement with Latin America: The Community of Latin America and Caribbean States (CELAC), its Promise and Challenges." Chap. 6 in Re-mapping the Americas, edited by W. Andy Knight, Julián Castro-Rea and Hamid Ghany. Surrey: Ashgate Publishing Limited, 2014.

Knight, W. Andy, Julián Castro-Rea and Hamid Ghany, ed. Re-mapping the Americas. Surrey: Ashgate Publishing Limited, 2014.

Krapohl, Sebastian, Katharina L. Meissner and Johannes Muntschick. "Regional Powers as Leaders or Rambos? The Ambivalent Behavior of Brazil and South Africa in Regional Economic Integration." Journal of Common Market Studies 52, no. 4 (2014): 879- 895. doi:

$10.1111 / \mathrm{jcms} .12116$.

Ewout Lamé, "Net herkozen en Bouterse kondigt meteen economische rampspoed aan", NRC Handelsblad 15 July 2015; Starnieuws, 5 juli 2015, "Hoe komen we uit de precaire financiële situatie?" http://www.starnieuws.com/index.php/welcome/index/nieuwsitem/30084. Accessed 18 September 2015.

Layne, Christopher. "This Time It's Real: The End of Unipolarity and the Pax Americana". International Studies Quarterly, 56, 1 (2012): 203-13.

Lins, A. Rio-Branco (Rio de Janeiro and São Paulo: Jose Olympio), 1945.

Lloyd, S. 2010. "The unpaved road: Barriers to Guyana's integration with South America." Council on Hemispheric Affairs, 28 July. Available at www.coha.org/the-unpaved-road-barriersto-guyanas-integration-with-south-america/ (accessed 20 July 2013).

Mearsheimer, John J. The Tragedy of Great Power Politics. New York: Norton, 2001.

Menke, J. and O. Pérez. Surinamese Strategic Culture. Miami: Florida International University (Findings Report 24), 2012.

Montero, A. Brazil: Reversal of Fortune. Cambridge: Polity Press, 2014. 
Montoute, A. "Emerging players in the Caribbean: What implications for the Caribbean, their relations with the EU and the ACP?" European Centre for Development Policy Management (ECDPM), 116, June 2011. Available at www.ecdpm.org/dp116 (accessed 19 September 2014).

Mrgudovic, Nathalie. "Evolving approaches to sovereignty in the French Pacific."

Commonwealth and Comparative Politics 50, no. 4 (2012): 456- 473. doi:

$10.1080 / 14662043.2012 .729730$

Nye, Joseph. "Soft Power: The Means to Success in World Politics". New York: Public Affairs, 2004.

Payne, Anthony. The Political History of CARICOM. Kingston: Ian Randle Publishers, 2008.

Piantoni, Frédéric. L'enjeu migratoire en Guyane française: une géographie politique. Matoury, Guyane: Ibis Rouge Editions, 2009.

Riggirozzi, Pía. "Region, Regionness and Regionalism in Latin America: Towards a New Synthesis.” New Political Economy 17, no. 4 (2012). doi: 10.1080/13563467.2011.603827.

Riggirozzi, Pía. "Regionalism, activism, and rights: New opportunities for health diplomacy in South America." Review of International Studies 41, no. 2 (2015): 407- 428. Doi:

$10.1017 / \mathrm{S} 026021051400028 \mathrm{X}$.

Riggirozzi, Pía. "Regionalism through social policy: collective action and health diplomacy in South America." Economy and Society 43, no. 2 (2014): 432-454.

doi:10.1080/03085147.2014.881598.

Sanders, R. 2012. "French Bridge to Brazil: Whither Guyana and the Caribbean?" 20 January. Available at http://sirronaldsanders.com/viewarticle.aspx?ID=281 (accessed 2 February 2012).

Schenoni, "Ascenso y hegemonía: pensando a las potencias emergentes desde América del Sur". Revista Brasileira de Política Internacional 55, 1 (2012): 31-48.

Silva, B.F. da and G. de V. Silva. Relações Internacionais Brasil-Suriname: Uma Leitura a Partir dos Acordos Diplomáticos em Assuntos Econômicos (1975-2013). Porto Alegre: Ed. Letra1 (2014): 49-58.

Simonian, Ligia T.L. and Rubens da Silva Ferreira. "Brazilian Migrant Workers in French Guiana." In Caribbean Transnationalism: Migration, Pluralization, and Social Cohesion, edited by Ruben Gowrichard, 99-116. Lanham: Lexington Books, 2006. 
Soares De Lima and M. Hirst. "Brazil as an intermediate state and regional power: action, choice and responsibilities." International Affairs 82, no. 1 (2006): 21-40.

Soreanu Pecequilo, C. and Alves do Carmo, C. "Regional Integration and Brazilian Foreign Policy: Strategies in the South American Space." Revista De Sociologia E Política 21, no. 48 (2013): 51-65.

Stabroek News. 2009. "The security of the Guyana-Brazil border, 14 July. Available at http://www.stabroeknews.com/2009/opinion/editorial/07/14/the-security-of-the-guyanabrazil-border/ (accessed 19 July 2013).

Stabroek News. 2013. "Deeper Caricom integration will lead to more prosperity - Ramotar." 1 July. Available at www.stabroeknews.com/2013/news/stories/07/01/deeper-caricomintegration-will-lead-to-more-prosperity-ramotar/.

Stabroek News. 2014a. "Brazil recommits to Lethem road - hydro, port still on agenda." 29 August. Available at http://www.stabroeknews.com/2014/news/stories/08/29/brazilrecommits-lethem-road/ (accessed 24 April 2015).

Stabroek News. 2014b. "Guyana, Suriname trade with Brazil on 'slow burner'." 24 October. Available at http://www.stabroeknews.com/2014/business/10/24/guyana-suriname-tradebrazil-slow-burner/ (accessed 4 February 2015).

StarNieuws. 2009. "Ook dit is geen Suriname...." 29 December. Available at http://www.starnieuws.com/index.php/welcome/index/nieuwsitem/48 (accessed 1 May 2015).

StarNieuws. 2010. "Vijf mannen veroordeeld in Papatam-zaak." 6 December 2010. Available at http://www.starnieuws.com/index.php/welcome/index/nieuwsitem/3688, (accessed 1 May 2015).

StarNieuws. 2012a. "Braziliaanse missies voor uitdiepen agrarische sector." 24 April. Available at http://www.starnieuws.com/index.php/welcome/index/nieuwsitem/10480 (accessed 29 April 2015).

StarNieuws. 2012b. "Suriname opent consulaat in Belem." 21 November. Available at http://www.starnieuws.com/index.php/welcome/index/nieuwsitem/14150 (accessed 29 April 2015).

StarNieuws. 2012c. "Verdrag Suriname Brazilië unaniem goedgekeurd." 20 March. Available at http://www.starnieuws.com/index.php/welcome/index/nieuwsitem/9864 (accessed 29 April 2015). 
StarNieuws. 2013. "In oktober gezamenlijke grensexcursies Suriname en Brazilië." 20

September. Available at

http://www.starnieuws.com/index.php/welcome/index/nieuwsitem/19304 (accessed 29 April 2015).

Strange, Susan. "The Persistent Myth of Lost Hegemony." International Organization 41, 4 (1987): 551-574.

The Economist. "The Big Oily: The Petrobras Scandal Explained". The Economist, 3 January 2015. Available at: http://www.economist.com/news/americas/21637437-petrobras-scandalexplained-big-oily

Van Dijck, P. "Troublesome Construction: The Rationale and Risks of IIRSA." European Review of Latin American and Caribbean Studies 85, October (2008): 101-120.

Van Dijck, P. The Impact of the IIRSA Road Infrastructure Programme on Amazonia. Abingdon: Routledge, 2013.

Van Stipriaan, Alex. "Maroons and the Communications Revolution in Suriname's Interior". In In and out of Suriname: Language, mobility and identity, edited by Eithne B. Carlin, Isabelle Léglise, Bettina Migge, and Paul Tjon Sie Fat. Leiden: Brill, 2014: 154-155.

Vigevani, Tullo and Haroldo Ramanzini Júnior. "The Impact of Domestic Politics and International Changes on the Brazilian Perception of Regional Integration." Latin American Politics and Society 53, no. 1 (2011): 125-55. 